\title{
MULTIMODAL METHODS IN THE DIAGNOSIS OF CHANGES IN THE ORGAN OF VISION AT ATHEROSCLEROSIS
}

\author{
D. K. Makhkamova \\ (TIPME) Tashkent Institute of \\ Postgraduate Medical Education of \\ the Ministry of Health of \\ Republic of Uzbekistan, \\ Parkent, 51. 100007, \\ Uzbekistan, \\ Tashkent
}

Article DOI: https://doi.org/10.36713/epra4701

\section{RESUME}

Background. The study of the parameters of optical coherence tomography with angiography (OCTA) broadens the understanding of the state of hemodynamics for the early detection of vascular disorders of the organ of vision in atherosclerosis (AS).

Purpose. To study the parameters of OCTA with changes in the organ of vision against the background of AS.

Material and methods. 26 patients (41 eyes) with changes in the organ of vision in AS. The age contingent of patients ranged from 32 to 78 years, the average age was $47.5 \pm 2.0 \mathrm{~g}$, of which 10 were women, 16 men. Depending on the damage to target organs, all patients were conditionally divided into 2 groups: group I (19 eyes) included patients without damage, and group II (22 eyes) consisted of patients with target organs damage.

Results. The registration of OCTA in patients of group I, a decrease in the density of capillaries of the superficial vascular network was $15 \%$ and amounted to $45.21 \pm 2.62 \%$ ( $p<0.05)$, of the deep vascular plexus by $19 \%$, which amounted to $45.89 \pm 2,71 \%$ ( $p<0.05$ ). In the macular region, the area of the hypoperfused retina was $1.07 \pm 0.14 \mathrm{~mm} 2$ $(p<0.05)$. In the region of the optic nerve disc, areas of hypoperfusion were noted in the superficial layers in 7 eyes and in the deep layers in 4 eyes. Analysis of OCTA in patients of group II revealed a sharp decrease (by 48\%) in the density of capillaries in both the superficial and deep vascular plexuses of the retina, which amounted to $33.91 \pm 3.01 \%(p<0.05)$; $33.65 \pm 2.89 \%$ ( $p<0.05)$, respectively. In the macular region, the area of the non-perfused retina was $2.19 \pm 0.21 \mathrm{~mm} 2(p$ $<0.05$ ). In the area of the optic nerve disc, areas of nonperfusion were noted both in the surface layers and in the deep layers in 4 eyes.

Conclusion. The use of OCTA allows to detect changes in hemoperfusion in all layers of the retina and optic nerve in the early stages of AS development, which will allow early diagnosis and monitoring of the disease.

KEY WORDS: optical coherence tomography with angiography, ischemic diseases, organ of vision, atherosclerosis, hemoperfusion, vascular plexuses, retina and optic nerve.

\section{INTRODUCTION}

In recent years, atherosclerosis (AS) is considered to be a pathological process that most often affects the elderly and senile, but there is a tendency to "rejuvenate" the disease $[1,2]$.

Disruption of blood patency along the aperture and venous vascular bed leads to ischemic changes not only in the posterior, but also in the anterior segment of the eyeball with the development of secondary dystrophies $[4,5,6]$. At the same time, ophthalmic manifestations may be the only predictors of the development of acute circulatory disorders of the brain and heart. Therefore, early detection of disturbances in the hemocirculation of acute respiratory infections is an important task that will prevent the development of formidable diseases that threaten the patient's life.

In ophthalmology, methods for evaluating the hemodynamics of the eyeball have been widely used in recent years.one of the highly informative, easily accessible and non-invasive methods is optical coherence tomography with angiography mode (OCT-angiography (OCTA)). This method is characterized by calculating changes in the amplitude 
of optical rays reflected from tissues. The method is based on measuring the degree of amplitude decorrelation at a certain point in the optical B-scan when performing several consecutive b-scans (splitspectrum amplitude-decorrelation angiographySSADA), which is the result of changes in the characteristics of scattering and absorption of the beam at a particular scanning point over time.

The study of OCTA parameters expands the understanding of the state of the vascular network of the retina, optic nerve and choroid, which contributes to a detailed study of hemodynamics for early detection of vascular disorders of the organ of vision at AS without the introduction of dye [1-3].

Purpose of research. To study the parameters of optical coherence tomography with angiography for changes in the visual organ against the background of atherosclerosis.

\section{MATERIAL AND METHODS}

A total of 26 patients (41 eyes) with changes in organ of vision at AS were examined. The age group of patients ranged from 32 to 78 years, while the average age was $47.5 \pm 2.0 \mathrm{~g}$, of which 10 were women and 16 were men. The criterion for inclusion of patients in this study, according to the recommendations of WHO experts, was: the presence of dyslipidemia (increased levels of total cholesterol, triglycerides, lipoproteins), increased body mass index, smoking index, the ratio of the waist and hip circumferences, as well as AS (echographically, angiographically or coronarographically proven) damage to the vessels of the target organs. The exclusion criteria from this study were: the presence of diabetes mellitus, diseases of the organ of vision, acute disturbance of cerebral circulation, malignant and autoimmune diseases.

The diagnosis, as well as damage to target organs in atherosclerosis, was established by cardiologists, neurologists and angiosurgeons.

For scientific research, the approval of the Ethical Commission for Medical Research of the Ethical and Pharmaceutical Committee of the Republic of Uzbekistan was received in accordance with the Helsinki Declaration of the World Medical Association. Also, for inclusion in the research work, voluntary informed consent of the patients was obtained.

Depending on the damage to the target organs (brain and heart), all patients were conditionally divided into 2 groups: the first group (19 eyes) included patients without target organ damage, and the second group (22 eyes) consisted of patients with organ damage - targets.

All patients underwent a comprehensive examination, including a study of central visual acuity, kinetic and computer static perimetry, tonometry, gonioscopy, biomicroscopy, fundus ophthalmoscopy, ultrasound dopplerography of the vessels of the eye and brachiocephalic trunk.
For multimodal assessment of the (morphological and hemodynamic) parameters of optic nerve head and the retina, all patients were examined on the optic nerve head region $(\mathrm{ONH}$ protocol) and the macular region (RNFL, GCC) on an optical coherent tomograph with the TOPCON Triton plus angiography function (Ver. 10.13) (Swept Source OCT)

Scanning was carried out at a speed of 100,000 scans per 1 second. This mode allows you to receive OKTA-grams in the following sizes: $3 \times 3$, $4.5 \times 4.5,6 \times 6$ and $7.5 \times 7.5 \mathrm{~mm}$ with a resolution of $304 \times 304$ pixels. The retina scans were automatically segmented into "superficial", "deep" layers of the inner retina; outer retina and choriocapillary layer.

A statistical analysis of the data was carried out using the software package Statistica 6.0. The mean value (M), standard deviation (s) were determined. To compare the variational series, the Mann - Whitney, Wilcoxon, and Z-criteria were used. The critical significance level was 5\% (p $<0.05)$

\section{RESULTS AND DISCUSSION}

In the study of visual acuity, the indicators were within normal values and amounted to a maximum correction of $0.87 \pm 0.18(\mathrm{p}<0.05)$ with an average correction, intraocular pressure within 17.41 $\pm 0.21 \mathrm{~mm} \mathrm{Hg}(\mathrm{p}<0.05)$. When examining the visual fields in 6 eyes, relative scotomas were determined, in 5 eyes a concentric narrowing, 8 eyes without pathological changes in the visual fields.

When recording computer perimetric data, a decrease in retinal photosensitivity was noted - MD $2.51 \pm 0.11 \mathrm{~dB}$, PSD $3.59 \pm 0.09 \mathrm{~dB}(\mathrm{p}<0.05)$, relative scotomas were observed, an increase in the blind spot area while maintaining high acuity view.

A study on an optical coherence tomograph revealed a thickening of the layer of retinal nerve fibers (RNFL) of the upper and lower segments in 11 eyes, a thinning of the neuroretinal girdle (NRG) in 7 eyes, and a thinning of the para- and perifocal region in 8 eyes.

When registering OCTA in patients of the first group, there was a decrease in the density of capillaries of the superficial layer - the superficial vascular network by $15 \%$ and amounted to $45.21 \pm$ $2.62 \%(\mathrm{p}<0.05)$, of the deep layer - of the deep vascular network by $19 \%$, which $45.89 \pm 2.71 \%$ (p $<0.05)$. In the macular region, the area of the hypoperfused retina was $1.07 \pm 0.14 \mathrm{~mm} 2(\mathrm{p}<0.05)$. In area optic nerve head, hypoperfusion sites were noted in the superficial layers on 7 eyes, in the deep layers on 4 eyes (Fig. 1-see Appendix).

During ophthalmodopplerography, hemodynamically insignificant asymmetry of blood circulation was registered spasm of the ophthalmic artery (OA), Central retinal artery (CRA) and posterior short ciliary arteries (PSCA), the resistivity 
index (RI) was within normal values and amounted to (OA, CRA, PSCA) - 0.69; 0.65; 0.60 (respectively) $(\mathrm{p}<0.05)$. The condition of collateral blood circulation in the superficial temporal artery (STA) was within normal values.

In the study of patients of the second group, indicators of visual acuity with maximum correction were within $0.07 \pm 0.002(\mathrm{p}<0.05)$, intraocular pressure within $21.31 \pm 0.09 \mathrm{~mm} \mathrm{Hg}(\mathrm{p}<0.05)$. With kinetic perimetry, absolute scotomas were determined on 7 eyes, concentric narrowing on 7 eyes, and sectoral loss of visual fields on 8 eyes. The category of these patients showed a steady decrease in both central, peripheral and peripheral vision.

A study of the photosensitivity of the retina on computer perimetry recorded its decrease and amounted to - MD - $13.11 \pm 0.42 \mathrm{~dB}$, PSD $7.81 \pm$ $0.21 \mathrm{~dB}(\mathrm{p}<0.05)$. Also, a decrease in the photosensitivity of the paired eye was observed in patients of this group while maintaining high visual acuity.

The next category of patients showed changes in the parameters of OCT in the form of an increase in the area of the NRG (14 eyes) and a thickening of the RNFL in the peripapillary zone. The presence of areas of high neuroretinal edema (12 eyes) was also recorded here. High cystic edema of the macular area was registered in 9 eyes, which were subsequently recommended anti-VEGF therapy.

The analysis of OCTA in patients of the second group with damage to target organs revealed a sharp decrease (by $48 \%$ ) in the density of capillaries in both the superficial $-\mathrm{S}$ and deep $-\mathrm{D}$ vascular plexuses of the retina, which amounted to $33.91 \pm$ $3.01 \% \quad(p<0.05) ; \quad 33.65 \pm 2.89 \% \quad(p<0.05)$, respectively. In the macular region, the area of the non-perfused retina was $2.19 \pm 0.21 \mathrm{~mm} 2(\mathrm{p}<0.05)$ (Fig. 2 see Appendix). In the area of the optic disc, areas of nonperfusion were noted both in the surface layers and in the deep layers in 4 eyes.

During dopplerography, hemodynamically significant asymmetry of blood circulation parameters in the main vessels of the eye and extranial parts of brachiocephalic material was registered. Thus, the stability index of eye vessels was increased and amounted to RI (OA, CRA, PSCA) - 0.74; $0.71 ; 0.69$ (respectively) $(\mathrm{p}<0.05)$. When studying the consistency of collateral blood circulation in STA, a decrease in hemodynamic parameters was registered $(39.142,2.19 \mathrm{~cm} / \mathrm{S}$ $(\mathrm{p}<0.05))$ and an increase in the stability index (RI STA-0.72), which predicted an unfavorable course of the ischemic process [5].

In addition, in patients with target organ damage, a concomitant pathology was revealed in the form of grade I - II arterial hypertension (9 patients), chronic brain ischemia (7 patients), coronary heart disease (5 patients), which was not observed in patients without organ damage - targets.
To date, there are few works in the literature on the use of OCTA in vascular pathology of organ of vision $[2,9,12,13]$. Thus, the authors used the OCTA method for occlusion of the retinal veins, where they revealed the least perfusion in the ischemic type of occlusion of the retinal veins. There was a difference in perfusion indices with ischemic and non-ischemic types only with a scan area of $3 \times 3$ $\mathrm{mm}$. The authors, in addition to hypoperfusion in both the superficial and deep vascular network, observed the presence of microaneurysms and telangiectasias in the examined patients [12]. This proves that OCTA allows detecting perfusion disorders in all vascular layers of the central zone of the retina, as well as microvascular abnormalities in patients with retinal vein occlusion.

Gendelman I. and co-authors found an increase in blood flow deficit in choriocapillaries with its increase closer to the macular area in patients with diabetic retinopathy [13].

The authors of [16] note the high sensitivity $(89.2 \%)$ and specificity $(93.3 \%)$ of OCTA in detecting types of neovascularization of age-related macular degeneration, where the newly formed vessels are located under the pigment epithelium with a latent form of chronic neovascularization and classical with localization of the neovascular complex above pigmented epithelium.

\section{CONCLUSION}

This study revealed hemoperfusion disorders in all layers of the retina and optic nerve head in the early stages of the development of the AS process, when the target organs were not yet involved. This condition demonstrates the possibility of using the OCTA method for early identification of atherosclerosis in the early stages of the disease, which will prevent the disability of the population and prevent deaths.

With the generalization of atherosclerosis and damage to target organs, the use of OCTA allows monitoring of the ischemic process, which contributes to a more adequate management of patients with hemodynamic impairment of organ of vision in AS.

\section{BIBLIOGRAPHY/REFERENCES}

1. Будзинская М. В., Федоров А.А., Плюхова А.А., Воеводина Т.M., Балацкая Н.В. Морфологические проявления системного атеросклероза структур глазного дна (экспериментальное исследование). Вестник офтальмологии. 2013;129(2): 3-7 [M.V. Boudzinskaya, A.A. Fedorov, A.A. Plyukhova, T.M. Voyevodina, N.V. Balatskaya. Morphological manifestations of systemic atherosclerosis found in fundus (experimental study). Vestnik oftal'mologii. 2013; 129(2): 37.(In Russ.)]

2. Тульцева С.Н., Астахов Ю.С., Руховеи А.Г., Титаренко А.Н. Информативность ОКТ- 
ангиографии в сочетании с исследованиями регионарной гемодинамики при окклюзии вен сетчатки. Офтальмологические ведомости. 2017. T.10. №2. 40-48. [Tultseva S.N., Astakhov Ju.S., Rukhovets A.G., Titarenko A.N. Diagnostic value of oct-angiography and regional hemodynamic assessmentin patients with retinal vein occlusion. Oftal'mologicheskie vedomosti. 2017. T.10. №2. 40-48. (In Russ.)] https://doi.org/10.17816/ov10240-48

3. Cullinane D. C., Jenkins J. M., Schwartz M., Lavin P., Morris J. A. Anterior ischemic optic neuropathy: a complication after systemic inflammatory response syndrome. Journal of Trauma. - 2012. - Vol.48, №3. - P. 381-386. https://doi.org/10.1097/00005373-20000300000003

4. Makhkamova D.K. S100 marker in the diagnosis of ocular ischemic syndrome. OphthalmologicaKarger. 2014; 232 (1) 54-55.

5. https://doi.org/10.1159/000368726

6. Махкамова Д.К. Этиопатогенез развития глазного ииемического синдрома. Вестник офтальмологии. 2017;133(2): 120-124. [Makhkamova D.K. Etiopathogenesis of ocular ischemic syndrome. Vestnik oftal'mologii. 2017;133(2): 120-124. (In Russ.)].

7. Glueck S.J., Lim T. H. Giant cell arteritis causing bilateral sequential AION case report. Singapore Medical Journal. - 2004. - Vol. 41, №1. - P. 3233.

8. Wang Y, Fawzi AA, Varma R et al. Pilot study of optical coherence tomography measurement of retinal blood flow in retinal and optic nerve diseases. Investigative Ophthalmology and Visual Science. 2011; 52:840-845. https://doi.org/10.1167/iovs.10-5985

9. Jia Y, Morrison JC, Tokayer J et al. Quantitative OCT angiography of optic nerve head blood flow. Biomed Opt Express. 2012;3:3127-3137. https://doi.org/10.1364/boe.3.003127

10. Jia Y, Wei E, Wang X et al. Optical coherence tomography angiography of optic disc perfusion in glaucoma. Ophthalmology. 2014; 121:13221332. https://doi.org/10.1016/j.ophtha.2014.01.021

11. Srinivasan VJ, Adler DC, Chen $Y$ et al. Ultrahigh-speed optical coherence tomography for three-dimensional and en face imaging of the retina and optic nerve head. Investigative Ophthalmology and Visual Science. 2008; 49:5103-5110. https://doi.org/10.1167/iovs.082127

12. Аникина М.А., Матненко Т.Ю., Лебедев О.И. Оптическая когерентная томографияангиография: перспективный метод в офтальмологической диагностике. Практическая медииина. 2018;3(114):7-10. [Anikina M.A., Matnenko T.Ju., Lebedev O.I. Optical coherence tomography - angiography: a promising method in the ophthalmological diagnostics. Prakticheskaja medicina. 2018; 3(114):7-10. (In Russ.)]

13. Будзинская М. В., Шеланкова А. В., Михайлова М. А., Плюхова А. А., Нуриева Н. М., Фомин А. В. Изменения центтральной зонь глазного дна при ретинальных венозных окклюзиях по данным оптической когерентной томографии-ангиографии. Вестник офтальмологии. 2016;132(5): $15-22$ [Budzinskaya M. V., Shelankova A. V., Mikhaylova M. A., Plyukhova A. A., Nuriyeva N. M., Fomin A. V. Analysis of changes in central macular thickness based on optical coherence tomography angiography findings in retinal vein occlusion. Vestnik oftal'mologii. 2016;132(5): 15-22(In Russ.)]

14. https://doi.org/10.17116/oftalma2016132515-22

15. Gendelman I., Alibhai A.Y., Moult E.M., Levine E.S., Braun P.X., Mehta N., Zhao Y., Ishibazawa A., Sorour O.A., Baumal C.R., Witkin A.J., Reichel E., Fujimoto J.G., Duker J.S., Waheed N.K. Topographic analysis of macular choriocapillaris flow deficits in diabetic retinopathy using swept-source optical coherence tomography angiography. International Journal Retina Vitreous. 2020 Mar 19; 6:6. https://doi.org/10.1186/s40942-020-00209-0

16. Курышева Н.И., Маслова Е.В. Оптическая когерентная томография $c$ функцией ангиографии в диагностике глаукомь. Вестник офтальмологии. 2016;132(5): 98-102 [Kurysheva N.I., Maslova E.V. Optical coherence tomography angiography in glaucoma diagnosis. Vestnik oftal'mologii. 2016;132(5):98-102 (In Russ.)]. https://doi.org/10.17116/oftalma2016132598-102

17. https://doi.org/10.17116/oftalma20171332120 124

18. Park SH, Cho H, Hwang SJ, Jeon B, Seong M, Yeom H, Kang MH, Lim HW, Shin YU. Changes in the Retinal Microvasculature Measured Using Optical Coherence Tomography Angiography According to Age. Journal of Clinical Medicine. 2020 Mar 24;9(3). https://doi.org/10.3390/jcm9030883

19. Шаимов Т.Б., Панова И.Е., Шаимов Р.Б., Шаимова В.А., Шаимова Т.А., Фомин А.В. Оптическая когерентная томографияангиография в диагностике неоваскулярной формы возрастной макулярной дегенерации. Вестник офтальмологии. 2015;131(5): 4-13 [Shaimov T.B., Panova I.E., Shaimov R.B., Shaimova V.A., Shaimova T.A., Fomin A.V. Optical coherence tomography-angiography in the diagnosis of neovascular form of age-related macular degeneration. Vestnik oftal'mologii. 2015;131(5):4-13 (In Russ.)]. http://dx.doi.org/10.17116/oftalma201513154-12 
ISSN (Online): 2455-3662

EPRA International Journal of Multidisciplinary Research (IJMR) - Peer Reviewed Journal

Volume: 6 | Issue: 6 | June 2020 || Journal DOI: 10.36713/epra2013 || SJIF Impact Factor: 7.032 ||ISI Value: 1.188

\section{APPENDIX}

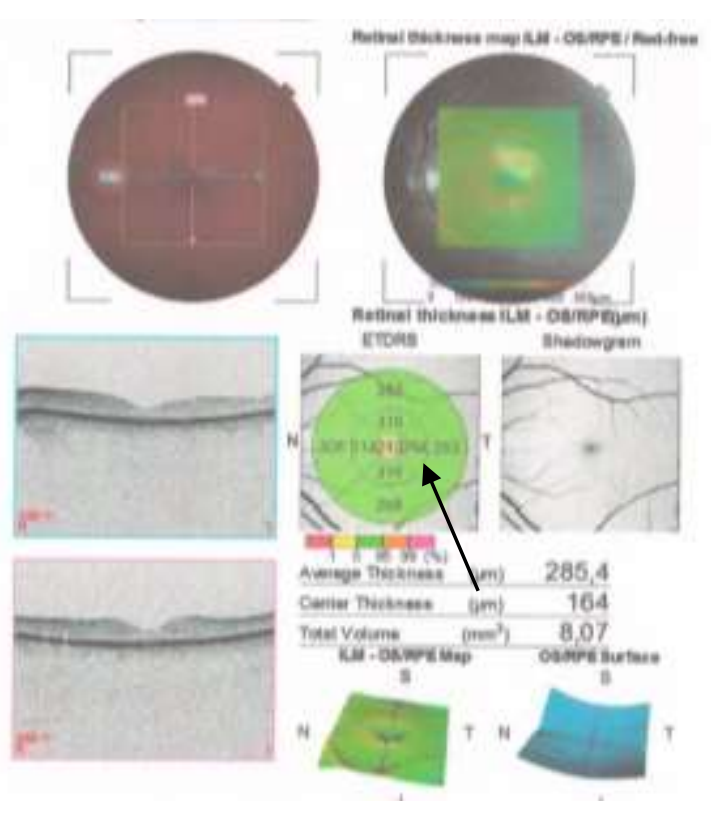

A

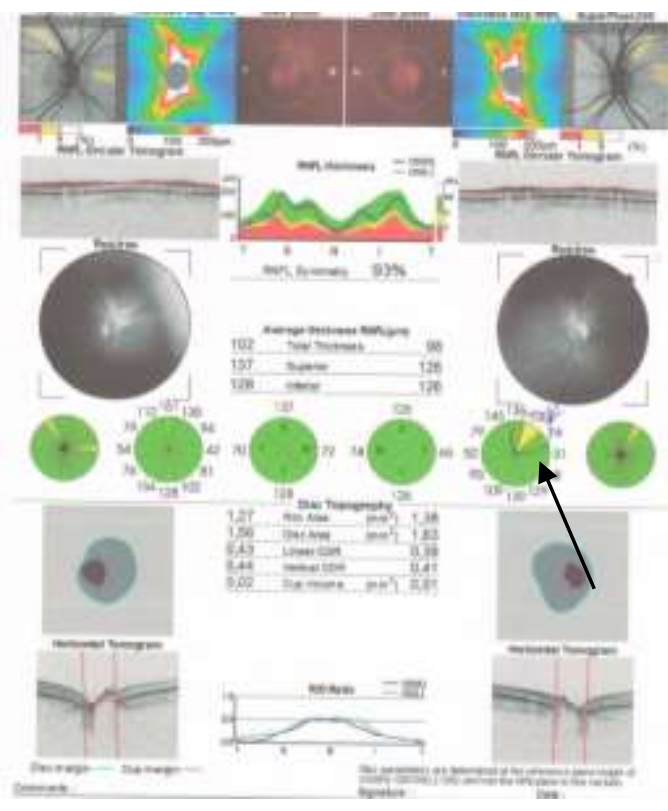

Б

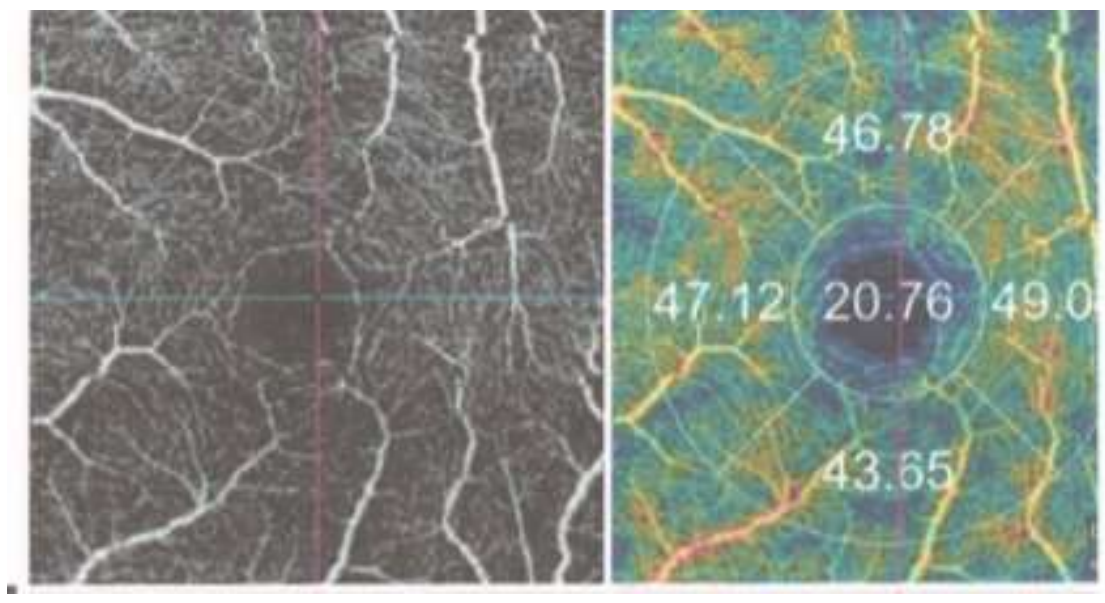

$\mathrm{B}$
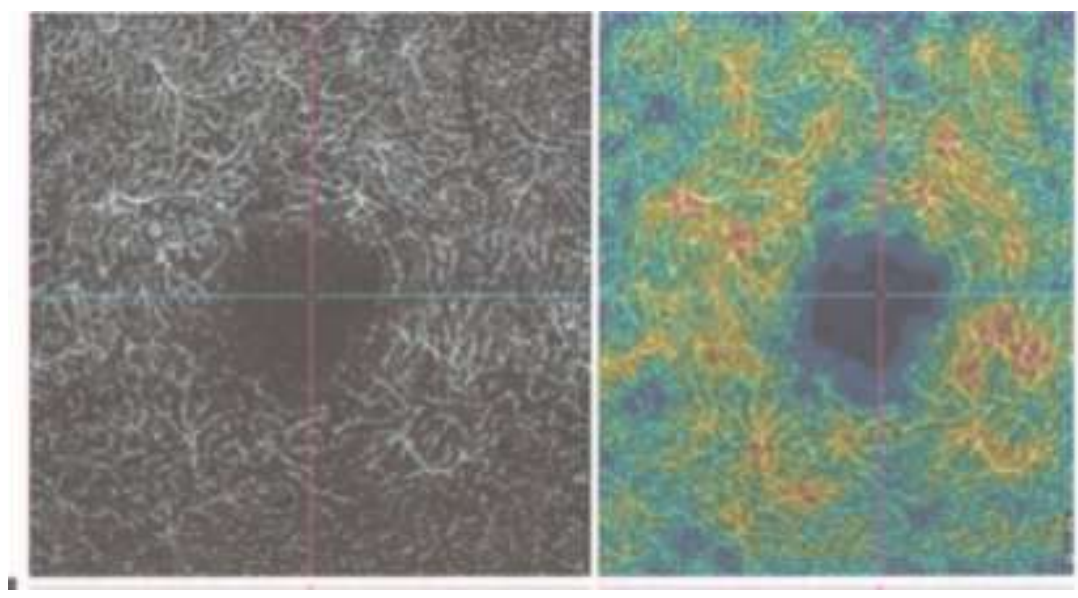


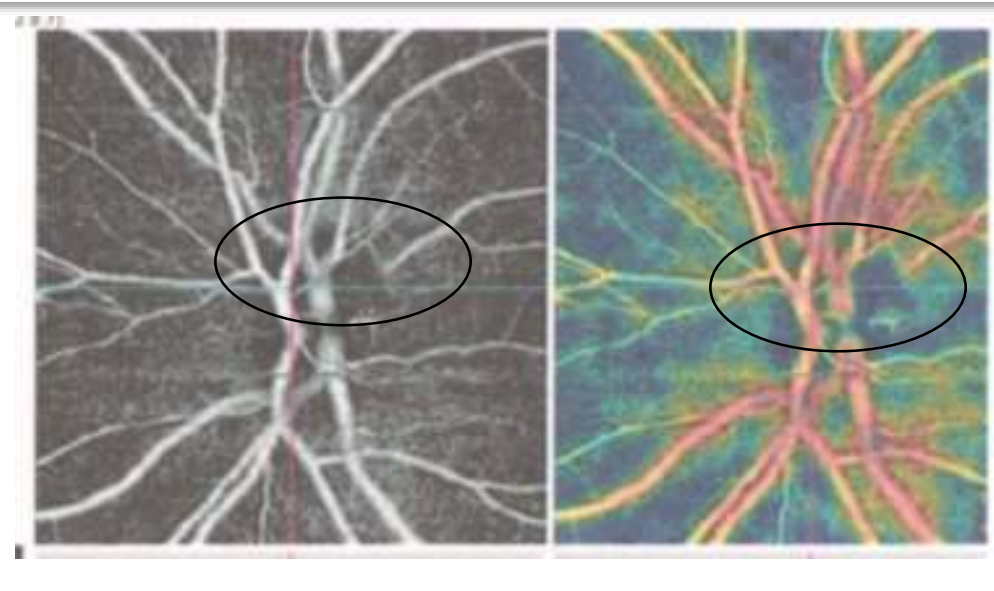

Д

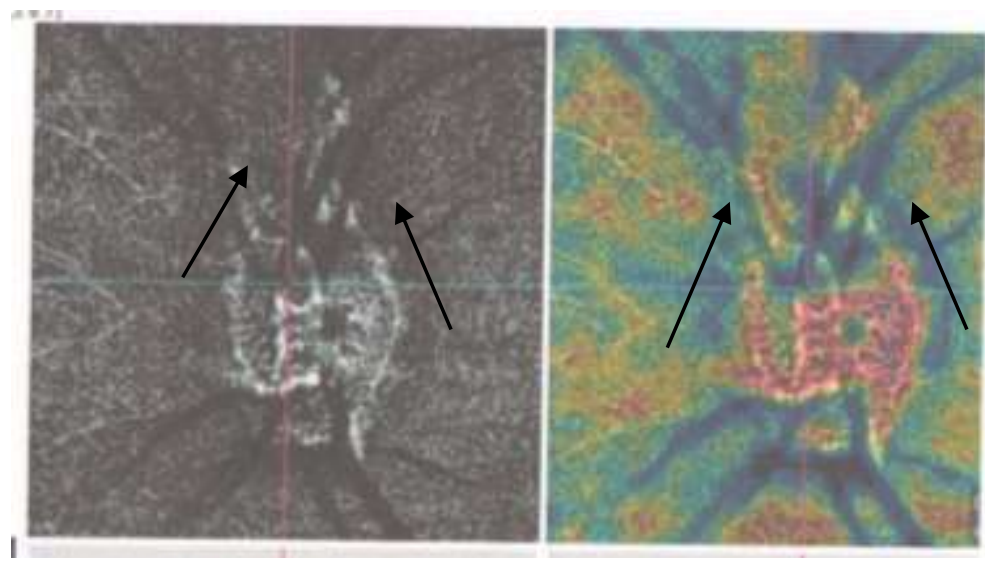

$\mathrm{E}$

Fig. 1. Optical coherence tomography with angiography of a patient of the 1st group (without damage to target organs) A - E. A - OCT in redless mode, visualized thinning of the foveal region (scan area $6 \times 6 \mathrm{~mm}$ ), $B$ - visualized of thinning of the neuroretinal girdle of the peripapillary region, $C, G$ - recorded hypoperfusion of the foveal region of the superficial $(B)$ and deep $(G)$ vascular plexuses (scanning area $3 \times 3 \mathrm{~mm}$ ), $D, E$ - recorded hypoperfusion of the optic nerve region of the superficial $(D)$ and deep $(E)$ vascular plexuses (scanning area $3 \times 3 \mathrm{~m}$ ). 
ISSN (Online): 2455-3662

EPRA International Journal of Multidisciplinary Research (IJMR) - Peer Reviewed Journal

Volume: 6 | Issue: 6 | June 2020 || Journal DOI: 10.36713/epra2013 || SJIF Impact Factor: 7.032 ||ISI Value: 1.188
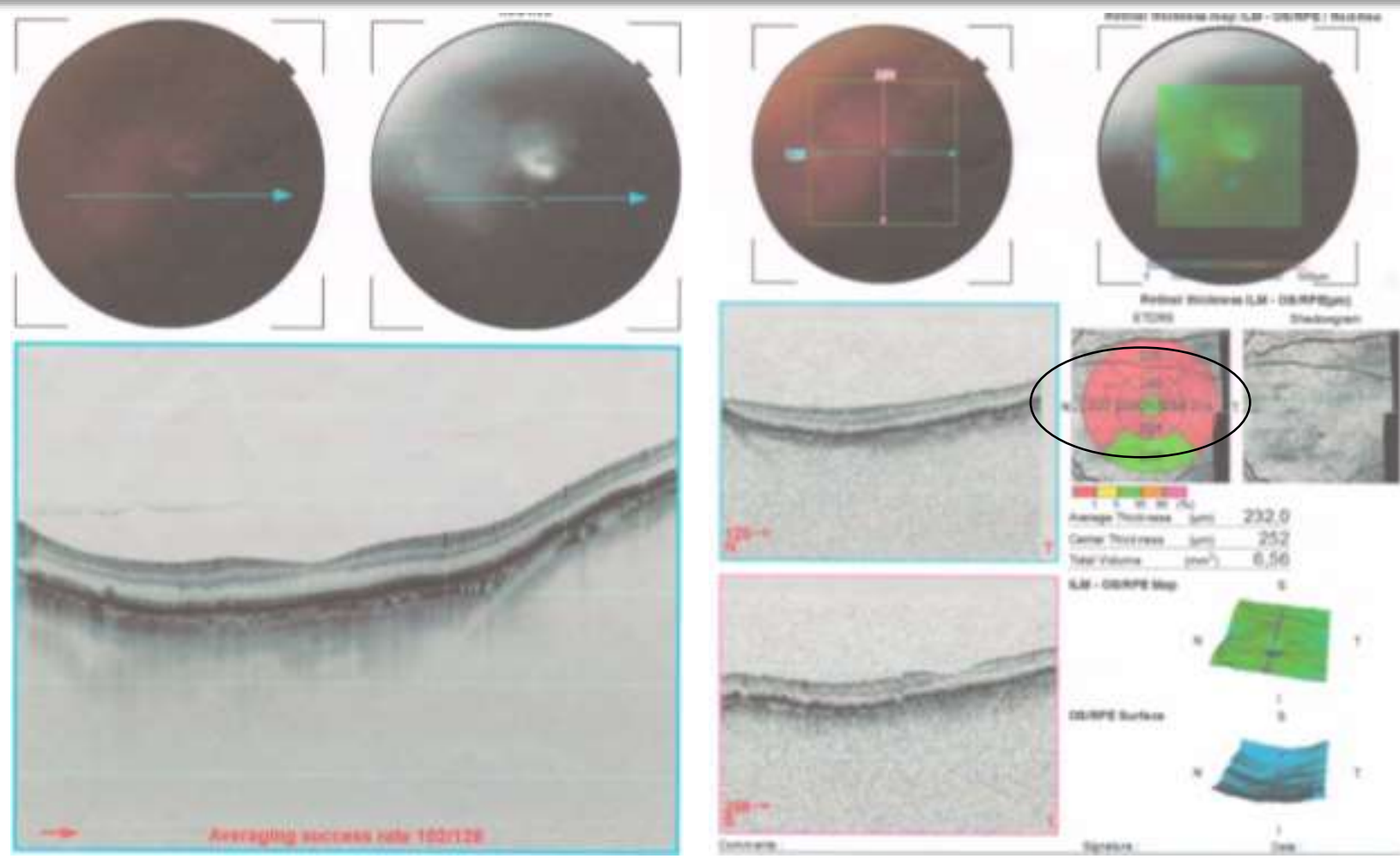

A

Б
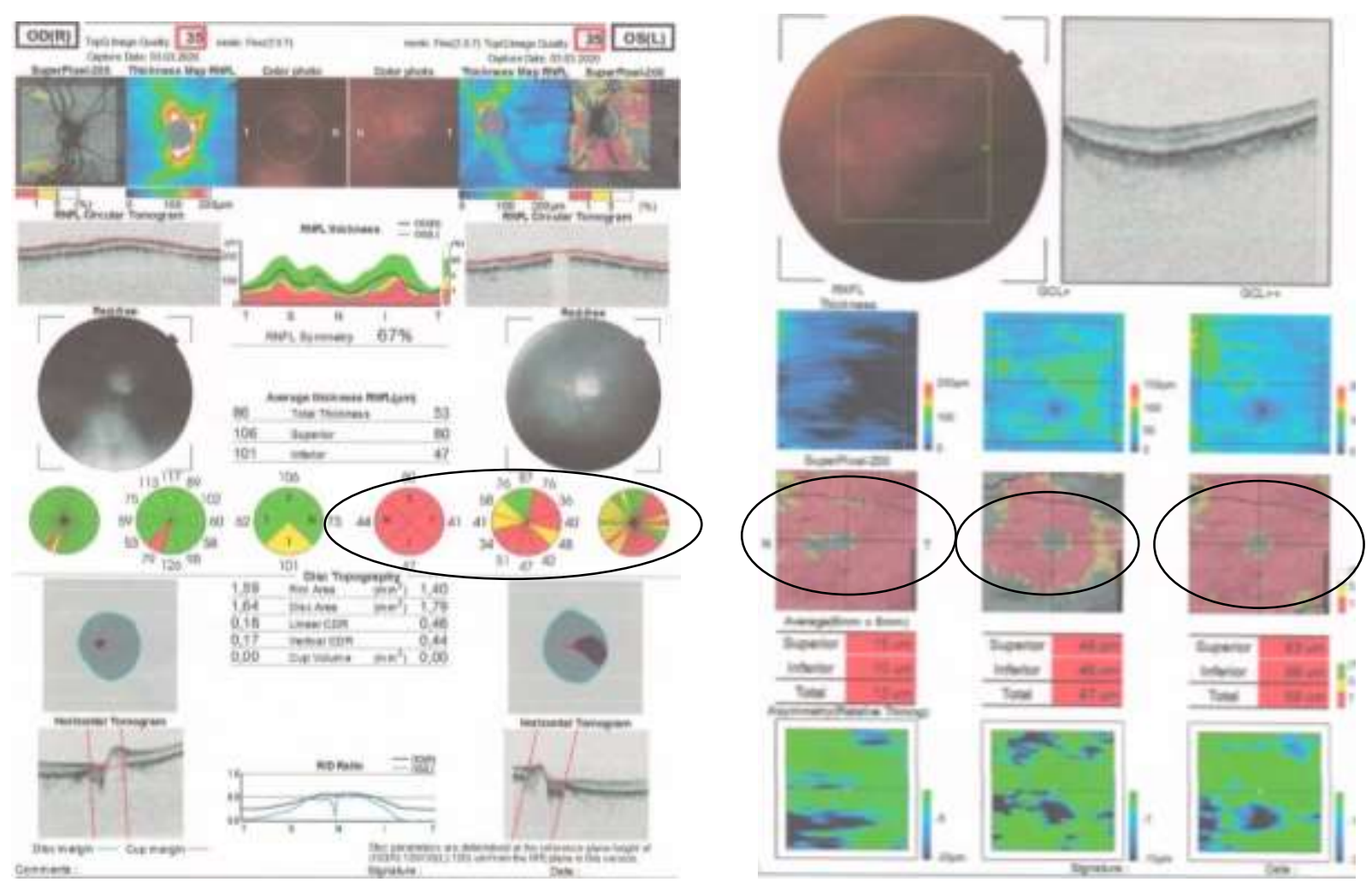

$\mathrm{B}$

$\Gamma$

Fig. 2. Optical coherence tomography with angiography of a patient of group 2 (with damage to target organs) A - G. A, B - OCT in redless mode, a sharp thinning of the parafoveal and perif oveal region, as well as the choriocapillary layer (scan area $6 \times 6 \mathrm{~mm}$ ) is visualized, $B, D-$ the thinning of the neuroretinal girdle and retinal nerve layer of the peripapillary region, a significant decrease in the thickness of the complex of retinal ganglion cells in the central zone (scan area $6 \times$ $6 \mathrm{~mm}$ ) are visualized.2020 EPRA IJMR | www.eprajournals.com | Journal DoI URL: https://doi.org/10.36713/epra2013 


\section{corresponding author :}

Dilbar Kamaldjanovna Makhkamova - MD, PhD Department of Ophthalmology,

Tashkent Institute of Postgraduate Medical Education.

Postal code: Uzbekistan, Tashkent, 100009, Maykurgan st., 53

https://orcid.org/0000-0001-6080-7680

http://www.researcherid.com/rid/D-1428-2015

https://publons.com/researcher/D-1428-2015

Phone: (+99899) 85727 09, (+99893) 5302043

Authors has no conflict of interests 